ARTICLE

https://doi.org/10.1038/s41467-019-12549-z

\title{
Marine nitrogen fixers mediate a low latitude pathway for atmospheric $\mathrm{CO}_{2}$ drawdown
}

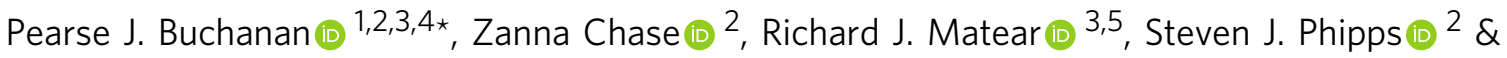 \\ Nathaniel L. Bindoff (1D 2,3,5,6
}

Roughly a third ( $\sim 30 \mathrm{ppm})$ of the carbon dioxide $\left(\mathrm{CO}_{2}\right)$ that entered the ocean during ice ages is attributed to biological mechanisms. A leading hypothesis for the biological drawdown of $\mathrm{CO}_{2}$ is iron $(\mathrm{Fe})$ fertilisation of the high latitudes, but modelling efforts attribute at most $10 \mathrm{ppm}$ to this mechanism, leaving $\sim 20 \mathrm{ppm}$ unexplained. We show that an Fe-induced stimulation of dinitrogen $\left(\mathrm{N}_{2}\right)$ fixation can induce a low latitude drawdown of 7-16 ppm $\mathrm{CO}_{2}$. This mechanism involves a closer coupling between $\mathrm{N}_{2}$ fixers and denitrifiers that alleviates widespread nitrate limitation. Consequently, phosphate utilisation and carbon export increase near upwelling zones, causing deoxygenation and deeper carbon injection. Furthermore, this low latitude mechanism reproduces the regional patterns of organic $\delta^{15} \mathrm{~N}$ deposited in glacial sediments. The positive response of marine $\mathrm{N}_{2}$ fixation to dusty ice age conditions, first proposed twenty years ago, therefore compliments high latitude changes to amplify $\mathrm{CO}_{2}$ drawdown.

\footnotetext{
${ }^{1}$ Department of Earth, Ocean and Ecological Sciences, University of Liverpool, L69 3GP Liverpool, UK. ${ }^{2}$ Institute for Marine and Antarctic Studies, University of Tasmania, Hobart 7004, Australia. ${ }^{3}$ CSIRO Oceans and Atmosphere, CSIRO Marine Laboratories, G.P.O Box 1538 Hobart, Tasmania, Australia. ${ }^{4}$ ARC Centre of Excellence in Climate System Science, Hobart, Tasmania 7004, Australia. ${ }^{5}$ ARC Centre of Excellence in Climate Extremes, Hobart, Tasmania 7004, Australia. ${ }^{6}$ Antarctic Climate and Ecosystems Cooperative Research Centre, Hobart, Tasmania 7004, Australia. *email: pearse.buchanan@liverpool.ac.uk
} 
A s much as $30 \mathrm{ppm}$ of the total glacial-interglacial difference in atmospheric $\mathrm{CO}_{2}$ is attributed to marine biological mechanisms ${ }^{1}$. The most prominent biological mechanism is the fertilisation of Fe-limited high latitude regions, namely the Southern Ocean ${ }^{2}$ and subarctic Pacific ${ }^{3}$, with dust-borne Fe under dusty glacial conditions 4,5 . Today, phytoplankton that inhabit these high latitude regions are unable to consume all available macronutrients, which allows $\mathrm{CO}_{2}$ to escape to the atmosphere as deep waters mix into surface layers. Iron fertilisation of the high latitude glacial ocean therefore stands as a leading hypothesis to explain a more efficient biological carbon (C) pump and the associated drawdown of atmospheric $\mathrm{CO}_{2}$. Yet, modelling focussed on the high latitudes has sequestered less than $10 \mathrm{ppm}$ of atmospheric $\mathrm{CO}_{2}$ via $\mathrm{Fe}$ fertilisation ${ }^{5-7}$ and indicates that additional biological mechanisms are required.

There are good reasons to accommodate the lower latitudes in our search for additional mechanisms. First, the region is enormous. Surface waters between $40^{\circ} \mathrm{S}$ and $40^{\circ} \mathrm{N}$ represent over two thirds of $\mathrm{CO}_{2}$ outgassing to the atmosphere ${ }^{8}$ and more than half of global $\mathrm{C}$ export ${ }^{9,10}$. Second, unconsumed phosphate $\left(\mathrm{PO}_{4}\right)$ at concentrations in excess of 0.1 to $0.2 \mathrm{mmol} \mathrm{m}^{-3}$ exists in surface waters across the tropics, which is evidence for unrealised biological $\mathrm{CO}_{2}$ fixation. Third, tropical oceans produce organic matter that is enriched in $\mathrm{C}$ because tropical phytoplankton are adapted to fix more $\mathrm{C}$ per unit phosphorus (P) under $\mathrm{P}$ scarcity ${ }^{11}$. Fourth, oxygen-deficient waters in the tropical Pacific, Indian and Atlantic allow organic matter to sink deeper into the ocean interior $^{10,12,13}$. If these mechanisms are combined, the cooccurrence of more complete $\mathrm{PO}_{4}$ utilisation and the production of $\mathrm{C}$-enriched organic matter near to oxygen-deficient zones would constitute an effective pathway of $\mathrm{CO}_{2}$ drawdown.

Enabling greater $\mathrm{PO}_{4}$ utilisation and $\mathrm{CO}_{2}$ drawdown in the lower latitudes, however, requires simultaneously relieving $\mathrm{Fe}$ limitation in upwelling zones ${ }^{14}$, nitrate $\left(\mathrm{NO}_{3}\right)$ limitation in the tropics $^{14,15}$ and their co-limitation at the boundary of both regimes $^{16}$. An aeolian Fe-induced stimulation of dinitrogen $\left(\mathrm{N}_{2}\right)$ fixation is therefore an obvious candidate to alleviate low latitude nutrient limitation. Originally proposed by Falkowski ${ }^{17}$, this mechanism is now supported by many independent lines of evidence. $\mathrm{N}_{2}$ fixers are highly sensitive to the aeolian supply of $\mathrm{Fe}^{18,19}$, they represent up to half of primary production and $\mathrm{C}$ export in oligotrophic waters ${ }^{20-24}$, they are physiologically adapted to $\mathrm{P}$ scarcity ${ }^{25,26}$, produce organic matter that is enriched in $\mathrm{C}^{27-29}$, and previous modelling has demonstrated the potential of $\mathrm{N}_{2}$ fixation to draw $\mathrm{CO}_{2}$ into the ocean ${ }^{30}$. Dinitrogen fixation is also inextricably linked to suboxic zones (dissolved oxygen
$\left.\left(\mathrm{O}_{2}\right)<10 \mathrm{mmol} \mathrm{m}^{-3}\right)$ where denitrification strips $\mathrm{NO}_{3}$ from the waters that upwell at the equator, creating a potential niche for $\mathrm{N}_{2}$ fixers across the wide expanse of the lower latitudes. The strength of $\mathrm{N}_{2}$ fixation, which strengthens $\mathrm{PO}_{4}$ utilisation, whole community C:P ratios and $\mathrm{C}$ export ${ }^{20}$, is thus tied to the strength of denitrification, which in turn strengthens $\mathrm{N}_{2}$ fixation.

In this study, we use an ocean model to demonstrate that aeolian $\mathrm{Fe}$ supply to the tropical oceans under glacial conditions $^{31,32}$ relieves low latitude nutrient limitation ${ }^{14-16}$ by stimulating $\mathrm{N}_{2}$ fixation, which in turn drives $\mathrm{PO}_{4}$ consumption, suboxic zone expansion, the acceleration of the nitrogen $(\mathrm{N})$ cycle and a more efficient $\mathrm{C}$ export to the interior ocean. Furthermore, we estimate the contribution of this mechanism to $\mathrm{CO}_{2}$ drawdown and reveal evidence of its existence within glacialinterglacial sedimentary records of $\mathrm{N}$ isotopes $\left(\delta^{15} \mathrm{~N}_{\text {org }}\right)$.

\section{Results}

A low latitude pathway. Inspired by these insights, we undertook multi-millennial simulations using a global ocean biogeochemical model to explore the link between Fe fertilisation, $\mathrm{N}_{2}$ fixation and $\mathrm{CO}_{2}$ drawdown. The ocean biogeochemical model is part of the Commonwealth Scientific and Industrial Research Organisation (CSIRO) Mark 3L-Carbon of the Ocean, Atmosphere and Land $(\mathrm{Mk} 3 \mathrm{~L}-\mathrm{COAL})^{33}$. The model is designed for long-term, global oceanographic studies. It resolves multi-millennial timescales and so produces equilibrium circulation states under a given set of atmospheric conditions. It is equipped with prognostic $\mathrm{C}, \mathrm{PO}_{4}$, $\mathrm{NO}_{3},{ }^{15} \mathrm{NO}_{3}$, and $\mathrm{Fe}$ cycles ${ }^{34}$ (see Methods), and includes a dynamic ecosystem component where phytoplankton alter their nutrient requirements, stoichiometry and remineralisation rates according to their environment ${ }^{33}$ (Supplementary Fig. 1). We increased the supply of aeolian Fe to the ocean model from its modern $^{35}$ to glacial rate $^{5}$ (see Methods; Supplementary Fig. 2) under preindustrial physical conditions (Mk3L $\mathrm{L}^{\text {mild }}$ state in Table 1; Supplementary Note 1; Supplementary Figs. 3 and 4; Supplementary Table 1) with an atmospheric $\mathrm{CO}_{2}$ held at 280 ppm, and assessed changes to elemental cycling. To isolate the response of the lower latitudes, we nudged subsurface Fe concentrations to $0.6 \mu \mathrm{mol} \mathrm{m}{ }^{-3}$ on a yearly timescale, which ensured that Fe was near non-limiting in regions of strong mixing, like the Southern Ocean and subarctic Pacific.

The glacial aeolian Fe supply increased the global rate of $\mathrm{N}_{2}$ fixation by $26 \mathrm{Tg} \mathrm{N} \mathrm{yr}^{-1}$ and caused a large-scale change in its distribution (Fig. 1a). Dinitrogen fixers exhibited a closer coupling to regions of strong upwelling in the tropics (solid

\section{Table 1 Global properties of the four ocean states}

\begin{tabular}{|c|c|c|c|c|c|}
\hline Variable & Units & GFDLwarm & Mk3L ${ }^{\text {mild }}$ & HadGEMcool & Mk3Lcold \\
\hline Tempa & $\left({ }^{\circ} \mathrm{C}\right)$ & 5.3 & 3.9 & 3.5 & 1.4 \\
\hline Sala & (psu) & 34.72 & 34.50 & 34.38 & 35.49 \\
\hline$\delta^{14} C^{a}$ & $(\% o)$ & -143.9 & -151.5 & -158.4 & -184.2 \\
\hline Surface $\mathrm{PO}_{4}{ }^{\mathrm{a}}$ & $\left(\mathrm{mmol} \mathrm{m} \mathrm{m}^{-3}\right)$ & 0.45 & 0.36 & 0.30 & 0.28 \\
\hline $\mathrm{O}_{2}^{\mathrm{a}}\left(\mathrm{AOU}^{\mathrm{a}}\right)$ & $\left(\mathrm{mmol} \mathrm{m} \mathrm{m}^{-3}\right)$ & $172(136)$ & 188 (134) & 222 (103) & $243(95)$ \\
\hline Suboxiab & (\% ocean) & 3.6 & 2.7 & 2.1 & 1.6 \\
\hline $\mathrm{NO}_{3}{ }^{\mathrm{a}}$ & $\left(\mathrm{mmol} \mathrm{m} \mathrm{m}^{-3}\right)$ & 22.1 & 22.4 & 24.0 & 28.9 \\
\hline$\Psi_{A A B W^{C}}$ & $(\mathrm{~Sv})$ & 7.2 & 11.5 & 11.4 & 39.0 \\
\hline$\Psi_{N A D W^{d}}$ & (Sv) & 20.3 & 18.4 & 13.0 & 13.0 \\
\hline$\frac{\partial \rho}{\partial z}(0-500 \mathrm{~m})^{\mathrm{e}}$ & $\left(\mathrm{kg} \mathrm{m}^{-3}\right)$ & $5.41 \times 10^{-3}$ & $5.06 \times 10^{-3}$ & $4.91 \times 10^{-3}$ & $6.39 \times 10^{-3}$ \\
\hline$\frac{\partial \rho}{\partial z}(1-2 \mathrm{~km})^{\mathrm{e}}$ & $\left(\mathrm{kg} \mathrm{m}^{-3}\right)$ & $0.51 \times 10^{-3}$ & $0.45 \times 10^{-3}$ & $0.65 \times 10^{-3}$ & $1.62 \times 10^{-3}$ \\
\hline
\end{tabular}



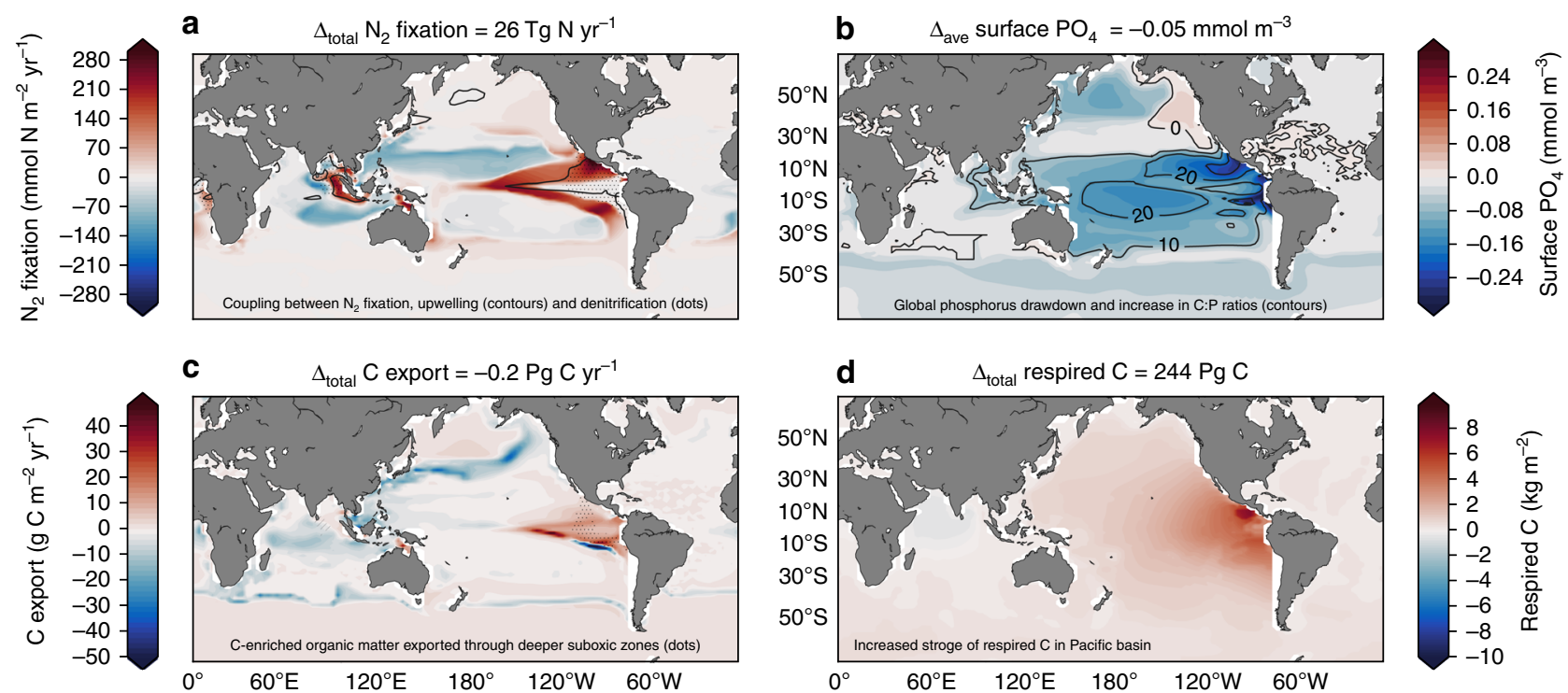

Fig. 1 Biogeochemical response to an Fe-induced stimulation of $\mathrm{N}_{2}$ fixers. Change in a $\mathrm{N}_{2}$ fixation rate, b surface $\mathrm{PO}_{4}$ concentration, c carbon export rate and $\mathbf{d}$ total respired carbon through the water column. The changes shown in both the coloured shading and the headings above each panel show the effect of increasing Fe deposition from the modern flux to the glacial flux ${ }^{5}$. The headings describe the integrated change $\left(\Delta_{\text {total }}\right)$ or the average change $\left(\Delta_{\text {ave }}\right)$ of each property, calculated as the volume or area weighted sum/average of each property. Dots in (a) represent active water column denitrification. Contours in (a) define upwelling where ideal water age $>25$ years at 80 metres depth. Contours in (b) are the change in C:P ratios of exported organic matter. Dots (dashes) in (c) define a vertical expansion (shrinking) of suboxia $>500$ metres

contour in Fig. 1a) that are co-located with areas of denitrification (dots in Fig. 1a). The greatest changes were observed in the Pacific. Dinitrogen fixation decreased in the Northwest Pacific and increased in the Eastern Tropical Pacific, which hosted low rates of $\mathrm{N}_{2}$ fixation under modern $\mathrm{Fe}$ supply (Supplementary Fig. 5a). As a result, surface $\mathrm{PO}_{4}$ was reduced throughout the tropical Pacific by between 0.1 and $0.2 \mathrm{mmol} \mathrm{m}^{-3}$ (Fig. 1b; Supplementary Fig. 5b). Pacific $\mathrm{PO}_{4}$ utilisation increased the C:P ratio of exported organic matter by an average of $\sim 14$ units (contours in Fig. 1b), which elevated local C export (Fig. 1c; Supplementary Fig. 5c), caused a vertical expansion of suboxia (dots in Fig. 1c), and enabled the permanent accumulation of 244 $\mathrm{Pg}$ of respired $\mathrm{C}$ in the eastern Pacific (Fig. 1d; Supplementary Fig. 5d). As a result, $11.6 \mathrm{ppm}$ of $\mathrm{CO}_{2}$ was permanently sequestered (see "Quantifying $\mathrm{CO}_{2}$ drawdown" and Fig. 2).

Dust-borne $\mathrm{Fe}$ fertilisation therefore involved a set of biogeochemical feedbacks, not possible by increasing the $\mathrm{NO}_{3}$ inventory (Supplementary Note 2; Supplementary Fig. 6), that enabled $\mathrm{CO}_{2}$ drawdown. Tropical upwelling zones are highly productive regions that drive strong subsurface $\mathrm{O}_{2}$ depletion, which in turn stimulates denitrification and strips upwelling waters of $\mathrm{NO}_{3}$. Consequently, the tropical Pacific hosts low $\mathrm{NO}_{3}$ : $\mathrm{PO}_{4}$ ratios (Supplementary Fig. 7a), which provides a competitive niche for $\mathrm{N}_{2}$ fixers. Today, the low supply of aeolian $\mathrm{Fe}$ to the tropical Pacific ${ }^{31,35}$ prevents $\mathrm{N}_{2}$ fixers from inhabiting this niche ${ }^{24}$, and allows excess, unconsumed $\mathrm{PO}_{4}\left(>0.2 \mathrm{mmol} \mathrm{m}^{-3}\right)$ to spill $10-15^{\circ}$ either side of the equator ${ }^{36}$ (Supplementary Fig. 7b). In contrast, the glacial Fe supply allowed $\mathrm{N}_{2}$ fixers to inhabit the low $\mathrm{NO}_{3}: \mathrm{PO}_{4}$ waters at the boundary to upwelling zones where local Fe-N co-limitation prevails today ${ }^{14,16}$. This shift in $\mathrm{N}_{2}$ fixation initiated strong biogeochemical feedbacks that encouraged $\mathrm{PO}_{4}$ utilisation, $\mathrm{C}$ export, suboxic expansion, denitrification, and a local $\mathrm{NO}_{3}$ supply via $\mathrm{N}_{2}$ fixation. Two consequences of this simulated feedback, the local increase in $\mathrm{C}$ export and a vertical expansion of suboxia, enabled the transfer of large amounts of C-rich organic matter deep within the interior of the Pacific basin (Fig. 1d).
Quantifying $\mathrm{CO}_{2}$ drawdown. We sought to quantify the sensitivity of atmospheric $\mathrm{CO}_{2}$ drawdown to the physical conditions of the ocean, as glacial conditions were distinct from pre-industrial ${ }^{37}$. We produced four different ocean states that can be considered broadly representative of glacial-interglacial conditions, encompassing warm to cold, well-mixed to stratified, and thus interglacial to glacial (Table 1; Supplementary Fig. 8). Dust-borne Fe supply was varied to $50,80,100,500 \%$ (glacial) and $2500 \%$ of the modern rate $\mathrm{r}^{35}$ over these four ocean states (see Methods) to fully encompass the glacial-interglacial range in conditions. Both high Fe deposition scenarios (500 and 2500\%) are based on the climatology of Lambert ${ }^{5}$, meaning that the delivery of $\mathrm{Fe}$ is not uniformly greater everywhere (Supplementary Fig. 2). The tropical Pacific, for instance, receives roughly 2-fold more Fe than under modern conditions consistent with recent estimates ${ }^{31,32}$. In addition, we increased and decreased the Fe requirements of $\mathrm{N}_{2}$ fixers without varying aeolian Fe deposition (See methods), which emulated variations in Fe supply but only to $\mathrm{N}_{2}$ fixers. If similar changes occurred via both methods, then $\mathrm{N}_{2}$ fixation could be considered the primary driver of $\mathrm{CO}_{2}$ drawdown.

The ocean states were GFDL warm, Mk3L mild (control state used previously), HadGEM ${ }^{\text {cool }}$ and Mk3L cold. GFDL ${ }^{\text {warm }}$ was the warmest, youngest (see $\delta^{14} \mathrm{C}$ ), most deoxygenated, $\mathrm{NO}_{3}$-deplete and $\mathrm{PO}_{4}$-rich ocean, with a rapid overturning circulation dominated by the upper cell. Mk3L $\mathrm{L}^{\text {mild }}$ and HadGEM ${ }^{\text {cool }}$ were cooler, fresher and formed greater quantities of Antarctic Bottom Water than GFDL ${ }^{\text {warm }}$. The key difference between Mk3L mild and HadGEM $^{\text {cool }}$ was the rate of North Atlantic Deep Water formation, which was stronger for $\mathrm{Mk} 3 \mathrm{~L}^{\text {mild }}$ and elevated surface $\mathrm{PO}_{4}, \mathrm{C}$ export, $\mathrm{O}_{2}$ consumption and denitrification rates. $\mathrm{Mk} 3 \mathrm{~L}^{\text {cold }}$ represented full glacial conditions. It was the coldest, saltiest, and oldest ocean state, featuring strong vertical density gradients that restricted $\mathrm{PO}_{4}$ supply and a greatly expanded lower overturning cell consistent with glacial conditions ${ }^{38}$.

An increase in Fe supply drew between 6.7 and $16 \mathrm{ppm}$ of atmospheric $\mathrm{CO}_{2}$ into the ocean (compare star and plus symbols in Fig. 2). Different ocean states (colours in Fig. 2) therefore 


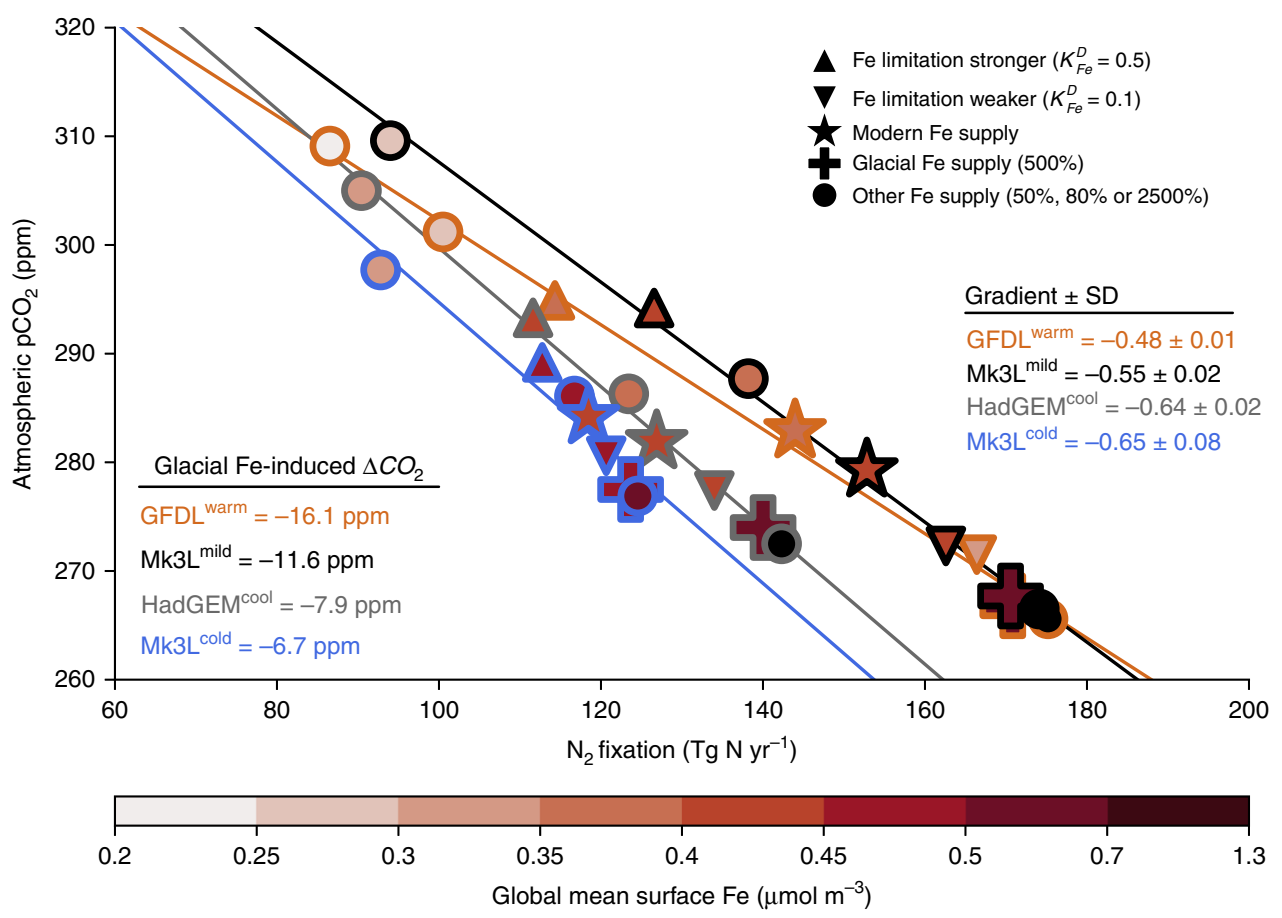

Fig. $2 \mathrm{~N}_{2}$ fixation and its relationship with atmospheric $\mathrm{CO}_{2}$. The atmospheric reservoir of $\mathrm{CO}_{2}$ was made responsive to oceanic uptake and release of $\mathrm{C}$ by the ocean (see methods). Coloured edges of markers correspond to ocean states as described in the figure legend. Star markers represent oceans with carbon cycles equilibrated to the modern Fe deposition ${ }^{36}$ under atmospheric $\mathrm{CO}_{2}$ of $-280 \mathrm{ppm}$. The plus symbol in each ocean state represents the change due to a glacial increase in Fe supply 6 , which represents a global integrated increase of $500 \%$ over the modern supply but is regionally variable (Supplementary Fig. 2). Triangles represent changes in the half-saturation constant for Fe limitation of $\mathrm{N}_{2}$ fixers, emulating changes in Fe supply to only $\mathrm{N}_{2}$ fixers. Note the diminishing gains in $\mathrm{CO}_{2}$ drawdown between 500 and $2500 \%$ iron deposition scenarios, consistent with $\mathrm{Fe}$-saturation and $\mathrm{PO}_{4}$ limitation. Regression lines and their slopes (gradient \pm standard deviation (SD)) represent the linear relationship between $\mathrm{N}_{2}$ fixation and atmospheric $\mathrm{CO}_{2}$, with a multi-ocean mean of $0.58 \pm 0.03 \mathrm{ppm} \mathrm{CO}_{2}$ sequestered for every additional $\mathrm{Tg} \mathrm{N} \mathrm{yr}^{-1}$. Source data are provided in the source data file

absorbed different quantities of $\mathrm{CO}_{2}$. However, all states developed a positive, linear relationship between $\mathrm{N}_{2}$ fixation and $\mathrm{CO}_{2}$ drawdown (coloured lines in Fig. 2). A consistent relationship between $\mathrm{N}_{2}$ fixation and $\mathrm{CO}_{2}$ drawdown suggested that all states absorbed atmospheric $\mathrm{CO}_{2}$ via the same low latitude pathway described in previously. Approximately $0.58 \pm 0.03 \mathrm{ppm}$ of $\mathrm{CO}_{2}$ was absorbed by the ocean for every additional Teragram of $\mathrm{N}$ fixed per year $\left(\mathrm{Tg} \mathrm{N} \mathrm{yr}^{-1}\right)$. The linear relationship was generated as $\mathrm{N}_{2}$ fixation responded to variations in $\mathrm{Fe}$ supply (circles) and as $\mathrm{N}_{2}$ fixation was made more or less sensitive to the modern supply of Fe (triangles). Similar responses occurred via both methods (altered $\mathrm{Fe}$ deposition and Fe requirements) and strongly implicated $\mathrm{N}_{2}$ fixation as the driver of $\mathrm{CO}_{2}$ drawdown.

The sensitivity of each ocean state to changes in $\mathrm{N}_{2}$ fixation was fundamentally linked to the strength of equatorial upwelling. The greatest sensitivity was found in GFDLwarm, which featured strong upwelling, and therefore high surface $\mathrm{PO}_{4}$ and large suboxic zones (Table 1). Consequently, large regions of the tropical ocean were low in $\mathrm{NO}_{3}: \mathrm{PO}_{4}$, which enabled large gains in $\mathrm{N}_{2}$ fixation $\left(88 \mathrm{Tg} \mathrm{N} \mathrm{yr}^{-1}\right.$ ) and $\mathrm{CO}_{2}$ drawdown (43 ppm) as $\mathrm{Fe}$ supply increased from 50 to $2500 \%$ of its modern rate. In contrast, $\mathrm{Mk} 3 \mathrm{~L}^{\text {cold }}$ featured the weakest rates of upwelling, lowest surface concentrations of $\mathrm{PO}_{4}$, the smallest suboxic zones (Table 1), and thus the weakest sensitivity. Phosphate availability therefore emerged as the ultimate control on biological $\mathrm{CO}_{2}$ drawdown by setting $\mathrm{N}_{2}$ fixation potential, while $\mathrm{Fe}$ supply modulated the extent to which this potential was realised.

A central role for $\mathbf{N}_{2}$ fixers. The previous experiments showed that $\mathrm{N}_{2}$ fixers responded to $\mathrm{Fe}$ addition leading to reduced atmospheric $\mathrm{CO}_{2}$. To elucidate the mechanisms through which this occurred we considered several additional experiments with the $\mathrm{Mk} 3 \mathrm{~L}^{\text {mild }}$ ocean state subject to variations in aeolian $\mathrm{Fe}$ supply. First, we removed $\mathrm{N}_{2}$ fixers and denitrification completely, thereby holding the $\mathrm{NO}_{3}$ reservoir constant. Second, we reinstated $\mathrm{N}_{2}$ fixers $\left(\mathrm{NO}_{3}\right.$ supply) and a marine $\mathrm{N}$ cycle (active denitrification), but removed their $\mathrm{C}$ export by setting their C:P ratio equal to zero. Third, we decreased their C:P ratio to $165: 1$, half its default of $331: 1^{39}$. Fourth, we reinstated their default C:P ratio of 331:1, but increased their $\mathrm{PO}_{4}$ half-saturation coefficient $\left(K_{P_{4}}^{D}\right)$ to $0.1 \mathrm{mmol} \mathrm{m}^{-3}$, which is the same as the general phytoplankton group and so removed their competitive advantage for $\mathrm{PO}_{4}$.

These experiments revealed that $\mathrm{N}_{2}$ fixers were essential for $\mathrm{C}$ accumulation via the low latitudes. If $\mathrm{N}_{2}$ fixers were removed and the $\mathrm{NO}_{3}$ reservoir remained constant, greater Fe supply did not cause respired $\mathrm{C}$ storage (ones in Fig. 3a). Insensitivity to $\mathrm{Fe}$ supply was due to widespread $\mathrm{NO}_{3}$ limitation of lower latitude ecosystems ${ }^{15}$. The simple addition of $\mathrm{N}_{2}$ fixers without changes in Fe increased $\mathrm{NO}_{3}$ supply to surface waters (Supplementary Fig. 9) and increased $\mathrm{PO}_{4}$ utilisation between $40^{\circ} \mathrm{S}$ and $40^{\circ} \mathrm{N}$ by $7 \%$. Dinitrogen fixers were, therefore, able to provide significant gains to the oceanic $\mathrm{C}$ store over millennia, which extends insights of in situ studies ${ }^{20-23}$ and prior modelling ${ }^{30}$ to the scale of the glacial cycles, as originally proposed by Falkowski ${ }^{17}$.

Dinitrogen fixers were therefore essential for oceanic $\mathrm{C}$ storage for the simple reason that they supplied fixed $\mathrm{N}$ to the upper ocean. Fixed $\mathrm{N}$ supply was responsible for $70 \%$ of the $\mathrm{C}$ gains $(\sim 5-11 \mathrm{ppm})$ and responsible for the increase in $\mathrm{PO}_{4}$ utilisation as Fe supply increased (compare ones and twos in Fig. 3a). 


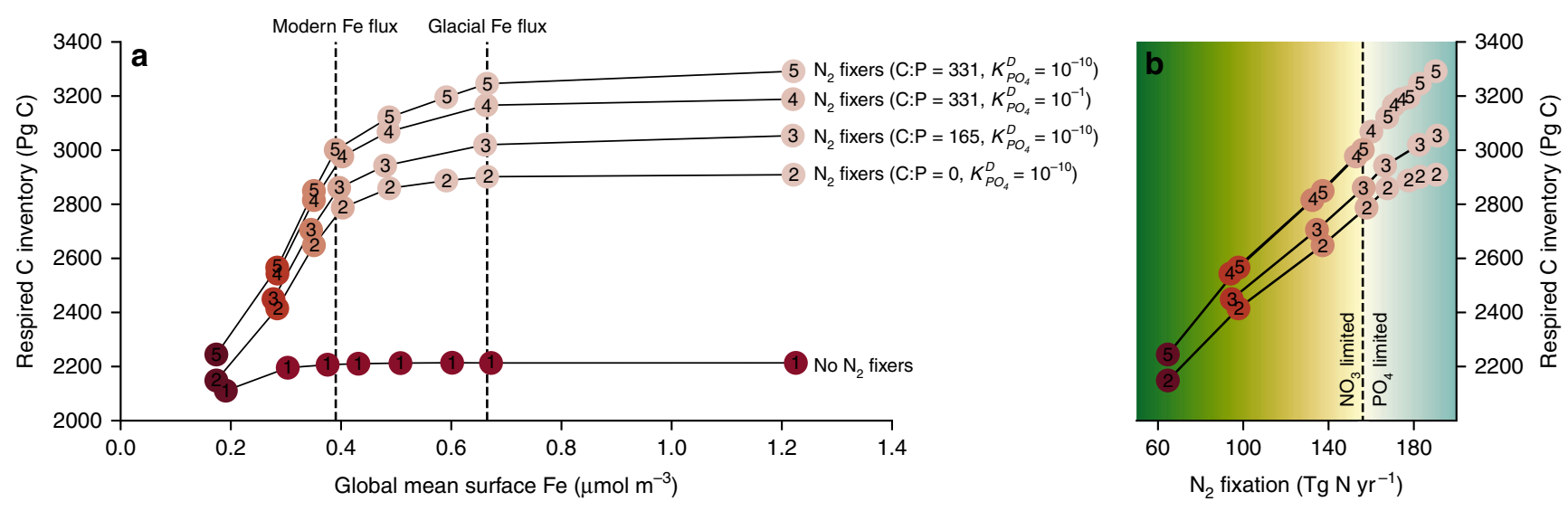

0.3

0.4

0.5

0.6

0.7

Global mean surface $\mathrm{PO}_{4}\left(\mathrm{mmol} \mathrm{m}^{-3}\right)$

Fig. 3 How $\mathrm{N}_{2}$ fixation enables $\mathrm{CO}_{2}$ storage in the ocean. The response of the respired $\mathrm{C}$ inventory to aeolian Fe deposition experiments for five different representations of $\mathrm{N}_{2}$ fixers, with $\mathbf{a}$ demonstrating the relationship between respired $\mathrm{C}$ and Fe availability and $\mathbf{b}$ demonstrating the relationship between respired $\mathrm{C}$ and $\mathrm{N}_{2}$ fixation. The marker numbers refer to how $\mathrm{N}_{2}$ fixers are represented. Ones: no $\mathrm{N}_{2}$ fixers and no active $\mathrm{N}$ cycle. Twos: $\mathrm{N}_{2}$ fixers and $\mathrm{N}$ cycle (i.e., denitrification) reinstated but no $N_{2}$ fixer carbon export ( $\left.C: P=0: 1\right)$. Threes: $N_{2}$ fixers $C: P$ ratio increased to 165:1, half its default value. Fours: $N_{2}$ fixers $\mathrm{PO}_{4}$ limitation enforced by increasing their half saturation coefficient $\left(K_{P_{4}}^{D}\right)$ from $10^{-10}$ to $0.1 \mathrm{mmol} \mathrm{m}^{-3}$. Fives: $\mathrm{N}_{2}$ fixers with default

parameterisation. Colour shading of the markers indicates the mean surface $\mathrm{PO}_{4}$ concentration of the experiment. Background shading in $\mathbf{b}$ is a qualitative indicator of the transition from $\mathrm{NO}_{3}$ to $\mathrm{PO}_{4}$ limitation, where dark green to yellow indicates $\mathrm{NO}_{3}$ limitation and light blue indicates $\mathrm{PO}_{4}$ limitation. Source data are provided in the source data file

Included within this $\mathrm{C}$ storage was the increase in $\mathrm{C}: \mathrm{P}$ ratios of Pacific Ocean phytoplankton as $\mathrm{PO}_{4}$ concentrations declined (see Fig. 1b). The final $30 \%\left(\sim 2-5 \mathrm{ppm} \mathrm{CO}_{2}\right)$ of additional $\mathrm{C}$ gain was mostly due to export of $\mathrm{N}_{2}$ fixer's $\mathrm{C}$-rich organic matter as the ocean became $\mathrm{PO}_{4}$-limited (compare ones, threes and fives in Fig. 3a), while their efficient utilisation of $\mathrm{PO}_{4}$ provided a small benefit to oceanic $\mathrm{C}$ storage (compare fours and fives in Fig. 3a). As $\mathrm{N}_{2}$ fixers already inhabit a niche of low $\mathrm{NO}_{3}: \mathrm{PO}_{4}{ }^{20}$, they are already at a competitive advantage over non- $\mathrm{N}_{2}$ fixing phytoplankton for available $\mathrm{PO}_{4}$.

The linear relationship between $\mathrm{N}_{2}$ fixation and $\mathrm{CO}_{2}$ drawdown, which was robust across different ocean states (Fig. 2), was therefore built on two phases. The first phase (green-yellow shading in Fig. $3 b$ ) occurred in a $\mathrm{NO}_{3}$-limited ocean, where $\mathrm{N}_{2}$ fixation increased the supply of $\mathrm{NO}_{3}$ to surface communities and thereby allowed excess $\mathrm{PO}_{4}$ to be consumed. The second phase (light blue shading in Fig. 3 b) occurred in a $\mathrm{PO}_{4}$-limited ocean. As $\mathrm{N}_{2}$ fixers consumed proportionally more of the remaining $\mathrm{PO}_{4}$, their $\mathrm{C}$ export became more important for overall $\mathrm{C}$ export (compare ones, threes and fours/fives Fig. 3b). The slope of the linear relationship presented in Fig. 2, therefore, rested on a C:P ratio of $\mathrm{N}_{2}$ fixer organic matter equal to $331: 1^{39}$. While there is significant variation around this number, under $\mathrm{PO}_{4}$-limiting conditions the C:P ratio tends to increase, exceeding 500:1 among Trichodesmium species ${ }^{28}$. Therefore, the C:P of $\mathrm{N}_{2}$ fixers could rise as $\mathrm{PO}_{4}$-limiting conditions develop and steepen the linear relationship to enable greater $\mathrm{CO}_{2}$ drawdown above that suggested here.

Glacial $\delta^{15} \mathbf{N}$ records. To test our proposed mechanism of low latitude $\mathrm{CO}_{2}$ drawdown against observations, we simulated the response of the isotopic composition of organic $\mathrm{N}\left(\delta^{15} \mathrm{~N}_{\text {org }}\right)$ to a glacial increase in Fe supply, and compared this response to a global compilation of glacial $\delta^{15} \mathrm{~N}$ records (Supplementary Data 1). These experiments were completed within each ocean state presented in Table 1, so as to isolate the effect of Fe fertilisation from the effects of physical changes. In the following, we discuss the response using the $\mathrm{Mk} 3 \mathrm{~L}^{\text {mild }}$ ocean state, but each ocean state gave a similar response (Supplementary Fig. 10).

An Fe-induced coupling of $\mathrm{N}_{2}$ fixers to the upwelling zones of the eastern tropical Pacific increased $\delta^{15} \mathrm{~N}_{\text {org }}$ in the west and decreased it in the east, which broadly reproduced patterns of glacial-interglacial change throughout the Pacific basin (Fig. 4). The increase in the western part of the basin was due to local decreases in $\mathrm{N}_{2}$ fixation and sedimentary denitrification, both of which lower $\delta^{15} \mathrm{~N}$. Our simulation of higher $\delta^{15} \mathrm{~N}_{\text {org }}$ in the west Pacific, therefore, supports the interpretation of a recent foraminifera-bound record in the South China Sea ${ }^{40}$ (star marker). However, the simulated decrease in the $\delta^{15} \mathrm{~N}$ of the eastern Pacific was not caused by a decrease in water column denitrification as suggested by numerous studies since the seminal paper of Ganeshram et al. ${ }^{41}$. Instead, our simulated decrease in eastern $\delta^{15} \mathrm{~N}_{\text {org }}$ was caused by increases in both sedimentary denitrification and $\mathrm{N}_{2}$ fixation (Fig. 1a).

However, poor agreement was found in other regions, namely in the tropical western Atlantic and Southern Ocean where an increase in $\delta^{15} \mathrm{~N}_{\text {org }}$ was not simulated. In the west Atlantic, Straub et al. ${ }^{42}$ presented a compelling relationship between $\delta^{15} \mathrm{~N}$ and orbital precession, leading the authors to surmise a dependence on the upwelling of $\mathrm{PO}_{4}$ via changes in the circulation. In the Southern Ocean, a glacial increase in $\delta^{15} \mathrm{~N}$ in Subantarctic ${ }^{2}$ and Antarctic zones ${ }^{43,44}$ is explained by a weaker physical delivery of $\mathrm{NO}_{3}$ to the mixed layer combined with $\mathrm{Fe}$ fertilisation. We therefore expected and found no response in both regions in these experiments (Supplementary Fig. 10) because the only change was an increase in dust-borne Fe and the Southern Ocean was made insensitive to increases in Fe supply.

\section{Discussion}

Our study confirms that $\mathrm{N}_{2}$ fixation is a key component of the global $\mathrm{C}$ cycle. We extend a theoretical proposal made over 20 years ago ${ }^{17}$ to a quantifiable mechanism of $\mathrm{CO}_{2}$ drawdown. The main biogeochemical feedbacks are illustrated in Fig. 5, where a 


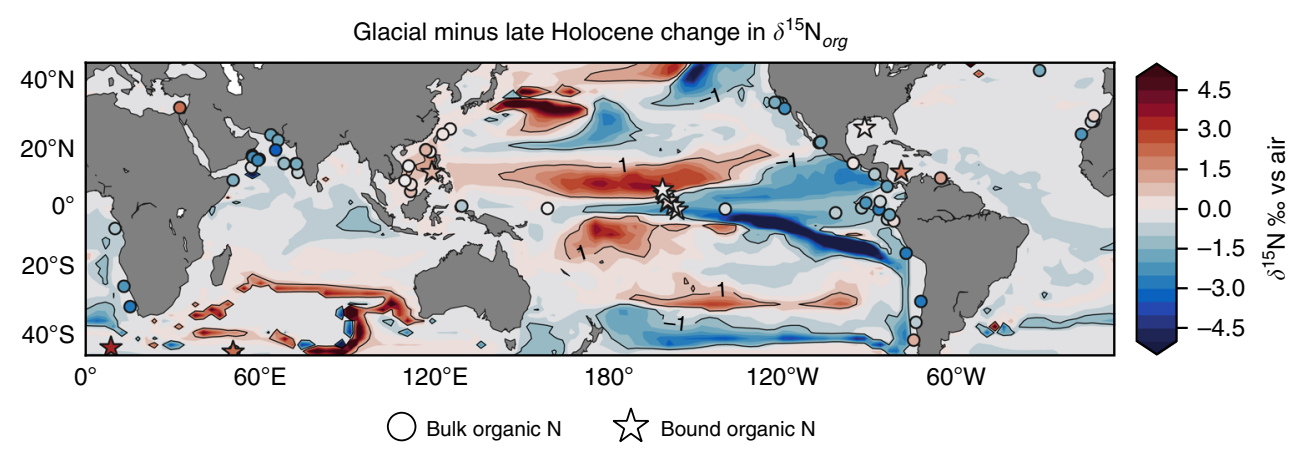

Fig. 4 Seeking evidence from sedimentary $\delta^{15} \mathrm{~N}_{\text {org }}$ records. Shading depicts the simulated change in $\delta^{15} \mathrm{~N}$ of organic matter as a result of increasing aeolian Fe supply from the modern to a glacial rate. Solid and dashed contour lines mark simulated differences of 1 and -1 . Circles mark locations of sediment cores where bulk organic matter was analysed for $\delta^{15} \mathrm{~N}$, while stars mark locations where either foraminifera- or diatom-bound $\delta^{15} \mathrm{~N}$ was measured. The colour of the markers is an estimate of the glacial (Last Glacial Maximum: 20,000-26,000 BCE) minus interglacial (Late Holocene: 0-5000 BCE) difference in $\delta^{15} \mathrm{~N}_{\text {org }}$, with red colours representing higher values and blues representing lower values in the glacial ocean. Sedimentary record data are provided in Supplementary Data 1
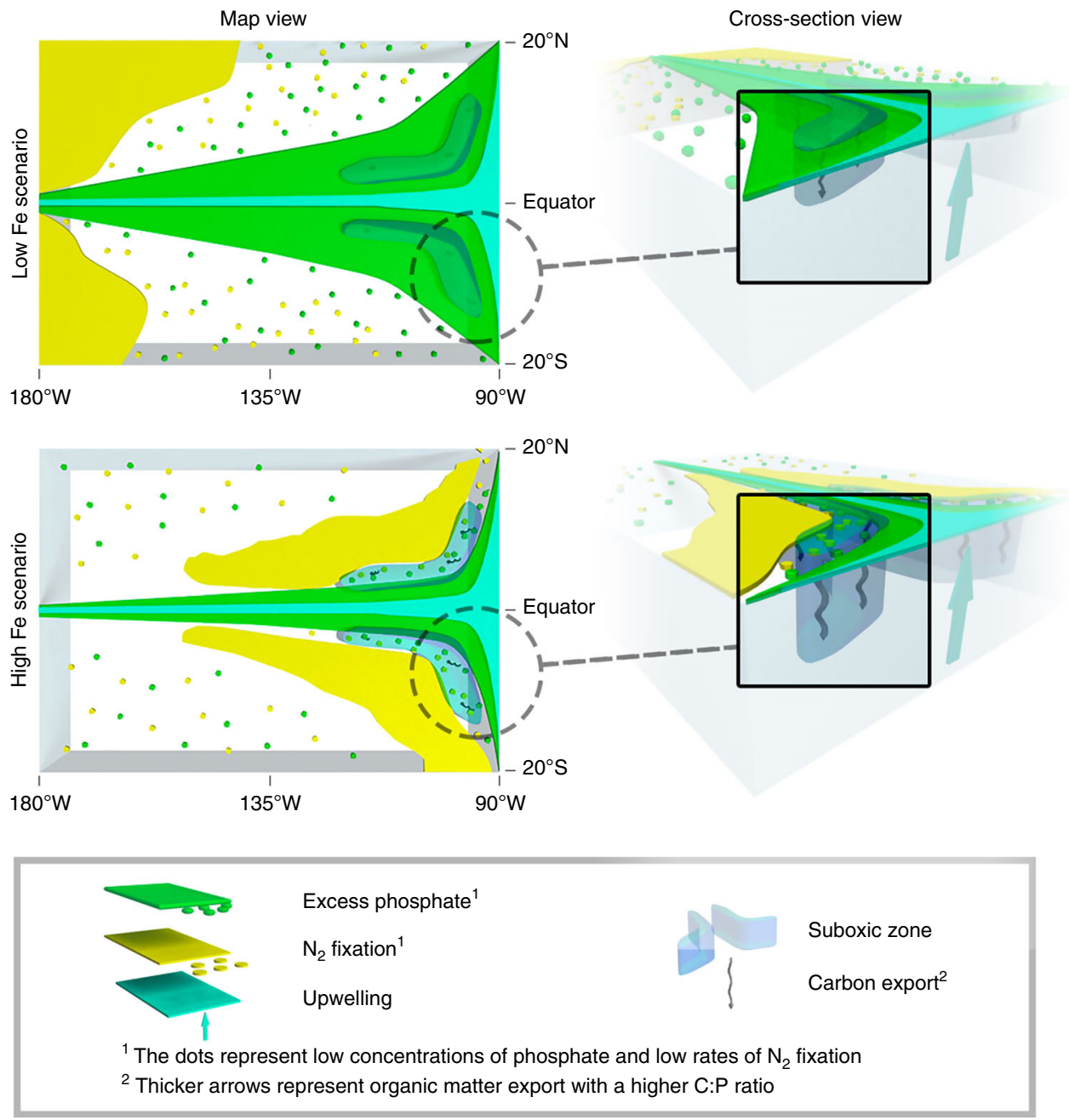

Fig. 5 Scenarios of Fe supply to the tropical Pacific. In the low iron scenario, analogous to the modern climate, $\mathrm{N}_{2}$ fixation (yellow zone and dots) is concentrated in the Northwest and Southwest subtropical Pacific where aeolian dust deposition is greatest. Non-limiting $\mathrm{PO}_{4}$ concentrations (green zone and dots) exist within the tropics and spread laterally from the area of upwelling near the Americas and at the equator (blue zone). In the high Fe scenario, analogous to the glacial climate, $\mathrm{N}_{2}$ fixation couples to the upwelling zones in the east Pacific, enabling strong utilisation of $\mathrm{PO}_{4}$, the vertical expansion of suboxic zones (grey bubbles) and a deeper injection of carbon-enriched organic matter (downward squiggly arrows) 
coupling of $\mathrm{N}_{2}$ fixers to upwelling zones is the catalyst that drives $\mathrm{CO}_{2}$ drawdown.

The importance of $\mathrm{N}_{2}$ fixation for $\mathrm{CO}_{2}$ drawdown is relevant when assessing prior modelling work. Simulations of the glacial climate have struggled to explain the full drawdown of roughly 90 $\mathrm{ppm}^{45}$, unless they make manual, and therefore non-mechanistic, changes to biological functioning ${ }^{38,46}$. Furthermore, model studies that explore $\mathrm{Fe}$ fertilisation without considering variable stoichiometry and remineralisation rates ${ }^{6,7}$ have struggled to sequester more than $10 \mathrm{ppm}$ of $\mathrm{CO}_{2}$. The permanent sequestration of 7-16 ppm solely via the low latitudes, therefore, represents a new and complementary pathway to explain the glacial $\mathrm{CO}_{2}$ drawdown. Thinking conservatively given the stratified and therefore $\mathrm{PO}_{4}$-limited conditions of a glacial ocean ${ }^{37,42}$, we propose that one third, or $10 \mathrm{ppm}$, of the $30 \mathrm{ppm}$ attributed to $\mathrm{Fe}$ fertilisation ${ }^{1}$ can be explained by a closer coupling of $\mathrm{N}_{2}$ fixation to tropical upwelling zones.

It is important to recognise, however, that our simulations rendered eutrophic regions insensitive to Fe fertilisation. Consequently, we neglect the response of Fe-limited regions like the Southern Ocean that not only have demonstrated potential for $\mathrm{CO}_{2}$ drawdown ${ }^{5-7,38,45}$, but also influence low latitude biogeochemistry through mode and intermediate waters ${ }^{47}$. This work should therefore not be interpreted as a globally integrated response to Fe fertilisation. Instead, it isolates the response of the lower latitudes and offers important lessons. First, that the debated ${ }^{32,48,49} \mathrm{CO}_{2}$ drawdown via the tropics is possible. Second, that this drawdown can accompany and thus complement high latitude mechanisms of $\mathrm{CO}_{2}$ drawdown. Third, that this drawdown requires simultaneous relief from both $\mathrm{Fe}$ and $\mathrm{NO}_{3}$ limitation $^{14-16}$, which is plausibly achieved by stimulating $\mathrm{N}_{2}$ fixers with dust-borne Fe.

Our confidence in this $\mathrm{N}_{2}$ fixer-mediated mechanism is bolstered by our simulation of the glacial-interglacial changes in $\delta^{15} \mathrm{~N}_{\text {org }}$ within the Pacific basin. However, both the drawdown of $\mathrm{CO}_{2}$ and the reproduction of the $\delta^{15} \mathrm{~N}_{\text {org }}$ patterns in our study hinge on an acceleration of $\mathrm{N}$ cycling in the Eastern Tropical Pacific. By acceleration of $\mathrm{N}$ cycling, we mean an acceleration of the rates of $\mathrm{N}_{2}$ fixation and denitrification. Such an acceleration conflicts with a long-assumed deceleration of $\mathrm{N}$ cycling. Since Ganeshram et al. ${ }^{41}$, glacial records of low $\delta^{15} \mathrm{~N}_{\text {org }}$ are interpreted to reflect a massive deceleration of water column denitrification, which must have exceeded a deceleration of sedimentary denitrification caused by a loss of shelf area ${ }^{50}$. Instead, our simulations produced an increase in sedimentary denitrification under Fe fertilisation. While both possibilities can explain the trends in Pacific $\delta^{15} \mathrm{~N}_{\text {org }}$ because they both involve more sedimentary over water column denitrification, they diverge in the inferred intensity of $\mathrm{N}$ cycling.

New evidence questions a glacial deceleration of the $\mathrm{N}$ cycle in the Eastern Tropical Pacific. Recent work has revealed a vertical expansion of Pacific suboxic zones ${ }^{32,51}$, a feature reproduced by our Fe fertilisation simulations. While it is not well known whether sedimentary or water column denitrification is more sensitive to increases in suboxia, it seems unlikely that both would decrease as suboxic zones expanded. In fact, it seems more likely that sedimentary denitrification was stimulated as waters overlying the sediment became deoxygenated ${ }^{52}$ and as more organic carbon was buried within sediments ${ }^{53}$, while water column denitrification, which is centred within the thermocline ${ }^{54}$, was reduced in line with reduced rates of particle export ${ }^{55}$. If suboxic zones did expand vertically $32,51,52$ and local $\mathrm{N}$ cycling accelerated, then the coupling of $\mathrm{N}_{2}$ fixers to eastern upwelling zones and subsequent $\mathrm{CO}_{2}$ drawdown is legitimate.
The legitimacy of our proposal then requires explaining another apparent inconsistency in glacial records: how could less particle export ${ }^{55}$ in the tropical Pacific coincide with more $\mathrm{C}$ export? Our results suggest that an answer may be found in the combination of variable stoichiometry and deoxygenation. Strong $\mathrm{PO}_{4}$ utilisation and aeolian Fe supply enriches the $\mathrm{C}$ content of exported organic matter ${ }^{11,56}$, while deoxygenation enables a strong transfer of particles to depth ${ }^{10,12,13}$. If both features were present during glacial periods, then lower rates of particle export ${ }^{55}$ do not preclude more $\mathrm{C}$ export, and therefore $\mathrm{CO}_{2}$ drawdown.

Today, there are compelling signs that $\mathrm{N}_{2}$ fixation has strengthened within the Pacific since the industrial revolution ${ }^{57,58}$ and that suboxic zones are expanding 59,60 . Our experiments suggest that these changes are symptomatic of a stronger biological C pump, but even so, we propose that gains in $\mathrm{N}_{2}$ fixation remain unrealised. Evidence that $\mathrm{N}_{2}$ fixation is operating well below full capacity can be found in the excess $\mathrm{PO}_{4}$ that spreads $10-15^{\circ}$ outwards from tropical upwelling zones ${ }^{36}$ (Supplementary Fig. 7b) and the spatial decoupling of $\mathrm{N}_{2}$ fixation from denitrification ${ }^{24}$. Realising the full potential of $\mathrm{N}_{2}$ fixation appears primarily dependent on the delivery of aeolian Fe to the surface ocean. Like the high latitudes ${ }^{2,3}$, we find that the strength of the lower latitude biological $\mathrm{C}$ pump demonstrates a strong link to the Fe cycle. However, how the oceanic Fe cycle will change in the future is uncertain ${ }^{61}$, and undermines our ability to predict the ocean's role in atmospheric $\mathrm{CO}_{2}$ drawdown in the coming centuries.

\section{Methods}

Model. Model simulations were performed using the ocean component of the Commonwealth Scientific and Industrial Research Organisation (CSIRO) Mark 3L -Carbon of the Ocean, Atmosphere and Land (Mk3L-COAL) Earth system model. The ocean component is comprised of an ocean general circulation model (OGCM) described in Phipps et al. ${ }^{62}$ and an ocean biogeochemical model (OBGCM) described in Buchanan et al. ${ }^{33}$ and Buchanan et al. ${ }^{34}$. A more specific description of the $\mathrm{N}$ cycle and Fe cycle are presented in the supplement. The ocean model has a horizontal resolution of $2.8^{\circ}$ in longitude by $1.6^{\circ}$ in latitude, with 21 vertical levels. It is a coarse resolution, $z$-coordinate OGCM, allowing millennial timescales to be resolved.

The OBGCM is equipped with 13 prognostic tracers that can be grouped into carbon chemistry fields, oxygen fields, nutrient fields and age tracers. Carbon chemistry and air-sea gas exchange is parameterised according to the latest ocean model requirements ${ }^{63}$. Nitrogen isotope routines are described in Buchanan et $\mathrm{al}^{34}$. The cycling of organic matter considers three forms of phytoplankton. These are a general phytoplankton group $\left({ }^{G}\right), \mathrm{N}_{2}$ fixers (otherwise known as diazotrophs; ${ }^{D}$ ) and calcifiers. The general phytoplankton group is controlled by dynamic equations for organic matter production, remineralisation and stoichiometry according to the study of Buchanan et al. ${ }^{33}$. These equations allow the general phytoplankton group to represent variations in the biogeochemical properties of the marine ecosystem, which has positive effects on the simulation of global ocean biogeochemistry, particularly the $\mathrm{N}$ cycle. Meanwhile, $\mathrm{N}_{2}$ fixers and calcifiers follow more static equations. $\mathrm{N}_{2}$ fixers have fixed nutrient limitation functions and stoichiometry based on laboratory studies, but are also remineralised according to community composition. Remineralisation of both forms of organic matter is also conserved and passed to deeper grid boxes if oxygen is not sufficient The calcifying group, which only interacts with DIC and ALK species, produces particulate inorganic carbon at $8 \%$ of the rate at which the general phytoplankton group produces organic carbon. Its remineralisation rate is also fixed according to an $e$-folding depth-dependent decay, which transfers a large fraction of particulate inorganic carbon to the deep ocean.

Nitrogen cycle. Nitrate is introduced to the ocean through atmospheric deposition and $\mathrm{N}_{2}$ fixation. Atmospheric deposition adds $11.3 \mathrm{Tg} \mathrm{N}$ to the surface ocean each year using a prescribed monthly climatology ${ }^{64}$.

The addition of $\mathrm{NO}_{3}$ by $\mathrm{N}_{2}$ fixation is calculated by considering marine $\mathrm{N}_{2}$ fixers as a unique group of phytoplankton. $\mathrm{N}_{2}$ fixers consume $\mathrm{PO}_{4}$ and $\mathrm{Fe}$ at the surface ocean, and release $\mathrm{PO}_{4}, \mathrm{Fe}$ and $\mathrm{NO}_{3}$ at depth during remineralisation. The stoichiometry of $\mathrm{N}_{2}$ fixers is static, with a C:N:P:Fe ratio of 331:50:1:0.00064 according to physiological studies ${ }^{39,65,66}$. With this stoichiometry, we apply $\mathrm{O}_{\text {rem }}: \mathrm{P}$ and $\mathrm{N}_{\text {rem }}: \mathrm{P}$ requirements of 431 and 294.8 , respectively, using the equations of Paulmier et al. ${ }^{67}$ 
The export of phosphorus by $\mathrm{N}_{2}$ fixers $\left(P_{\text {exp }}^{D}\right)$ is calculated using a maximum growth rate $\mu^{D}(T)$ that is temperature dependent ${ }^{68}$, limitation terms dependent on the availability of $\mathrm{PO}_{4}, \mathrm{NO}_{3}$ and $\mathrm{Fe}$, and minimum thresholds to account for cold water $\mathrm{N}_{2}$ fixation ${ }^{69}$. These terms are applied against an export:production ratio $\left(S_{E: P}^{D}\right)$ in units of $\mathrm{mmol} \mathrm{P} \mathrm{m}^{-3}$ day $^{-1}$. $P_{\text {exp }}^{D}$ is calculated via:

$$
P_{\text {exp }}^{D}=S_{E: P}^{D} \cdot \mu^{D}(T) \cdot \max \left(0.01, \min \left(P O_{4_{\text {lim }}^{D}}, N O_{3_{\text {lim }}^{D}}, F e_{\text {lim }}^{D}\right)\right) \cdot(1-i c o)
$$

where

$$
\begin{gathered}
\mu^{D}(T)=\max \left(0.01,-0.0042 \mathrm{~T}^{2}+0.2253 \mathrm{~T}-2.7819\right) \\
P \mathrm{~S}_{\text {lim }}^{D}=\frac{\mathrm{PO}_{4}}{\mathrm{PO}_{4}+K_{P O_{4}}^{D}} \\
\mathrm{NO}_{3_{\text {lim }}^{D}}=e^{-N O_{3}} \\
F e_{\text {lim }}^{D}=\max \left(0.0, \tanh \left(2 \mathrm{Fe}-K_{\mathrm{Fe}}^{D}\right)\right)
\end{gathered}
$$

The Fe half saturation coefficient $\left(K_{F e}^{D}\right)$ was kept at $0.3 \mu \mathrm{mol} \mathrm{m}{ }^{-3}, 3 \times$ that of other phytoplankton, unless otherwise clearly defined as another value in our discussion of the results below. The $\mathrm{PO}_{4}$ half saturation coefficient $\left(K_{\mathrm{PO}_{4}}^{D}\right)$ was $10^{-10}$ unless otherwise clearly defined as another value to emulate $\mathrm{N}_{2}$ fixers efficient utilisation of $\mathrm{P}^{25,26}$. Light was also not considered as a limiting factor. A dependency on light was omitted because of the strong correlation between incident radiation and sea surface temperature ${ }^{70}$ and its negligible effect on $\mathrm{N}_{2}$ fixation in the Atlantic Ocean ${ }^{71}$. Finally, the fractional area coverage of sea ice (ico) is included to ensure that no cool-water $\mathrm{N}_{2}$ fixation ${ }^{69}$ occurs under ice. The remineralisation of $\mathrm{N}_{2}$ fixer export occurs at the same rate as other labile organic matter produced by the general phytoplankton group.

Two processes remove $\mathrm{NO}_{3}$ from the ocean model: water column and sedimentary denitrification. Water column denitrification occurs when $\mathrm{O}_{2}$ concentrations are less than a particular threshold $\left(R_{\text {lim }}^{O_{2}}\right)$, which is set at $7.5 \mathrm{mmol}$ $\mathrm{O}_{2} \mathrm{~m}^{-3}$. We calculate the fraction of organic matter $\left(P_{\text {org }}\right)$ that is remineralised by water column denitrification via:

$$
f_{\text {den }}=\left(1-e^{-0.5 \cdot R_{\text {lim }}^{O_{2}}}+e^{\mathrm{O}_{2}-0.5 \cdot R_{\text {lim }}^{\mathrm{O}_{2}}}\right)^{-1}
$$

and then apply the appropriate stoichiometric requirements of $\mathrm{NO}_{3}$ to this fraction of $P_{\text {org: }}$ :

$$
\Delta \mathrm{NO}_{3}\left(W C_{\text {den }}\right)=f_{\text {den }} \cdot P_{\text {org }} \cdot \mathrm{N}_{\text {rem }}: \mathrm{P}
$$

Following this, the strength of water column denitrification is reduced if the ambient concentration of $\mathrm{NO}_{3}$ is deemed to be limiting. Water column denitrification depletes $\mathrm{NO}_{3}$ towards concentrations between 15 and $40 \mathrm{mmol} \mathrm{m}^{-3}$ in modern suboxic zones ${ }^{36}$. Without this additional constraint, here defined as $r_{d e n}$, $\mathrm{NO}_{3}$ concentrations quickly go to zero in simulated suboxic zones. We calculate $r_{d e n}$ by prescribing a lower limit at which $\mathrm{NO}_{3}$ can no longer be consumed $\left(R_{\text {lim }}^{\mathrm{NO}_{3}}\right)$, which was set to $30 \mathrm{mmol} \mathrm{NO}_{3} \mathrm{~m}^{-3}$ :

$$
\begin{gathered}
r_{W C_{d e n}}=0.5+0.5 \cdot \tanh \left(0.25 \cdot \mathrm{NO}_{3}-0.25 \cdot R_{l i m}^{\mathrm{NO}_{3}}-2.5\right) \\
\text { if } r_{W C_{d e n}}<f_{d e n}, \text { then } f_{d e n}=r_{W C_{d e n}}
\end{gathered}
$$

Sedimentary denitrification was calculated using the paramaterisation of Bohlen et al. ${ }^{72}$, where the removal of $\mathrm{NO}_{3}$ is dependent on the rain rate of organic carbon to the sediments $\left(C_{\text {org }}\right)$ and the ambient concentrations of $\mathrm{O}_{2}$ and $\mathrm{NO}_{3}$.

$$
\Delta \mathrm{NO}_{3}\left(S_{\text {den }}\right)=\left(\alpha+\beta \cdot 0.98^{\left(\mathrm{O}_{2}-\mathrm{NO}_{3}\right)}\right) \cdot C_{\text {org }}
$$

The $\alpha$ term was 0.08 , while the $\beta$ term was halved compared the original value of Bohlen et al. ${ }^{72}$ to $\beta=0.1$ in an attempt to increase the deep $\mathrm{NO}_{3}$ inventory. The availability of $\mathrm{NO}_{3}$ for sedimentary denitrification was accounted for according to the equation:

$$
r_{S_{\text {den }}}=0.5+0.5 \cdot \tanh \left(10 \cdot \mathrm{NO}_{3}-5\right)
$$

Thus, sedimentary denitrification was relaxed towards zero as $\mathrm{NO}_{3}$ concentrations became low.

If $\mathrm{NO}_{3}$ was limiting, the remaining organic matter was remineralised using $\mathrm{O}_{2}$, so long as the environment was sufficiently oxygenated. The availability of oxygen in the sediments was estimated to be two-thirds of the overlying bottom water concentration, based on observations of transport across the diffusive boundary layer by Gundersen and Jorgensen ${ }^{73}$. Furthermore, an additional limitation was set for sediments underlying hypoxic waters $\left(\mathrm{O}_{2}<40 \mathrm{mmol} \mathrm{m}^{-3}\right)$, where aerobic remineralisation was diminished towards zero according to the hyperbolic tangent function:

$$
r_{S_{\text {rem }}}=0.5+0.5 \cdot \tanh \left(0.2 \cdot \mathrm{O}_{2}-5\right)
$$

If both $\mathrm{NO}_{3}$ and $\mathrm{O}_{2}$ were limiting, the remaining organic matter was assumed to be remineralised via sulfate reduction.
Subgrid-scale bathymetry. A large amount of sedimentary remineralisation was not included using these parameterisations because the coarse resolution OGCM enables it to resolve only the largest continental shelves. Many small areas of raised bathymetry in pelagic environments were also unresolved. To address this insufficiency, we coupled a sub-grid scale bathymetry to the course resolution OGCM following the methodology of Somes et al..$^{74}$ and using the ETOPO5 $\frac{1}{12}^{\text {th }}$ of a degree dataset. For each latitude by longitude grid point, we calculated the fraction of area that would be represented by shallower levels in the OGCM if this finer resolution bathymetry were used. At each depth level above the OGCM's deepest level, the fractional area represented by sediments on the sub-grid scale bathymetry was used to remineralise all forms of organic matter via the sedimentary processes defined above.

Iron cycle. Our simulated Fe cycle involves a prescribed external source via the aeolian deposition of dust ${ }^{35}$, and an internal control in water masses in contact with the ocean floor. The internal control relaxes Fe concentrations to a set concentration given in the control file, which is set to $0.6 \mu \mathrm{mol} \mathrm{m}{ }^{-3}$ over a period of 1 year. The iron cycle, therefore, considers an atmospheric source, internal cycling via organic matter, and deep ocean sources and sinks via the sediments.

Simulations. All experiments were simulated for 10,000 years to achieve steadystate solutions of major biogeochemical tracers. Unless clearly defined otherwise, all experiments were run under preindustrial conditions, $M \mathrm{Mk}^{\mathrm{L}} \mathrm{L}^{\text {mild }}$, driven by monthly climatologies of surface conditions over an annual cycle. Surface climatologies required to force the OGCM and OBGCM under Mk3L $\mathrm{L}^{\text {mild }}$ conditions were generated by a 10,000 year pre-industrial (PI) control run of the flux corrected CSIRO Mk3L v1.2 climate system model in fully coupled mode ${ }^{62}$.

We forced the OGCM with three sets of additional boundary conditions to generate cold, cool and warm ocean states in addition to $\mathrm{Mk}^{2} \mathrm{~L}^{\text {mild }}$. The glacial ocean state (Mk3L cold $)$ was generated by forcing the CSIRO Mk3L climate system model with glacial conditions as simulated in Buchanan et al. ${ }^{38}$. Warm and mild conditions of GFDL ${ }^{\text {warm }}$ and HadGEM ${ }^{\text {cool }}$, respectively, were provided by the preindustrial control runs of the GFDL-ESM2G and HadGEM2-CC climate system models from the Climate Model Inter-comparison Project phase 5 (CMIP5) multimodel ensemble ${ }^{75}$. More thorough physical analyses of these ocean states are contained in Buchanan et al. ${ }^{38}$ and Buchanan et al. ${ }^{33}$.

Iron deposition experiments that varied Fe supply to the surface ocean involved altering the field of Mahowald et al. ${ }^{35}$ with constant factors to achieve 25, 50, 75, 80, $90,100,125,150,200,300$, and $400 \%$ of the modern flux. Higher fluxes representative of the glacial field were undertaken using the dust deposition fields of Lambert et al. ${ }^{5}$ assuming $3.5 \% \mathrm{Fe}$ content and 0.4 and $2 \%$ solubility, respectively, to achieve 500 and $2500 \%$ of the modern Fe supply rate (Supplementary Fig. S2). The glacial dust deposition rate referred to in the main text is the $500 \%$ version of the Lambert et al. ${ }^{5}$ field (Supplementary Fig. 2). These rates of Fe deposition were applied to the Mk $3 \mathrm{~L}^{\text {mild }}$ state and discussed in "A central role for $\mathrm{N}_{2}$ fixers", while a subset of these Fe deposition experiments, as well as variations in the Fe half-saturation constant for $\mathrm{N}_{2}$ fixers (see Supplementary description of the $\mathrm{N}$ cycle), were undertaken in with multiple physical states discussed in "Quantifying $\mathrm{CO}_{2}$ drawdown".

For those experiments with a freely evolving atmospheric $\mathrm{CO}_{2}$ concentration (within section "Quantifying $\mathrm{CO}_{2}$ drawdown"), we initialised each with the near-equilibrium solution produced by holding atmospheric $p \mathrm{CO}_{2}$ at $280 \mathrm{ppm}$ and with the modern $\mathrm{Fe}$ deposition (stars in Fig. 2), such that experiments with modern Fe deposition maintained atmospheric $p \mathrm{CO}_{2}$ near to $280 \mathrm{ppm}$. Altering Fe deposition then caused changes in air-sea $\mathrm{CO}_{2}$ exchange that altered the atmospheric and oceanic $\mathrm{C}$ reservoirs. The atmospheric $\mathrm{C}$ reservoir was calculated assuming a constant atmospheric weight of $5.1 \times 10^{21} \mathrm{~g}$ and a mean molecular weight of air of $28.97 \mathrm{~g} \mathrm{~mol}^{-1}$.

All experiments involved a relaxation of deep ocean Fe to values of $0.6 \mu \mathrm{mol} \mathrm{m}{ }^{-3}$ over a period of 365 days. Areas of connection between the deep and surface ocean, such as the high latitudes and deep upwelling zones, were therefore either non-Fe limited or almost non-Fe limited. This parameterisation rendered the high latitudes insensitive to greater Fe supply, while stratified lower latitudes were sensitive to $\mathrm{Fe}$ supply but $\mathrm{NO}_{3}$-limited.

$\delta^{15} \mathbf{N}_{\text {org }}$ records. Glacial minus interglacial values of $\delta^{15} \mathrm{~N}_{\text {org }}$ records were calculated by averaging values during the Last Glacial Maximum, defined as between 20 and $26 \mathrm{kya}$, and the Late Holocene, defined as between $0-5$ kya. The early Holocene was ignored due to transient changes in the $\delta^{15} \mathrm{~N}$ records since the deglaciation. The global compilation of $\delta^{15} \mathrm{~N}_{\text {org }}$ was composed of bulk sediment and diatom- and foraminifera-bound measurements, and is available in the supplementary material. A slight correction to simulated $\delta^{15} \mathrm{~N}_{\text {org }}$ was applied to correct for diagenetic effects that increase with depth in the water column. The addition of 0.9 per 1000 metres to the raw, simulated $\delta^{15} \mathrm{~N}_{\text {org }}$ values was applied and substantially improves comparisons between simulated and coretop values ${ }^{34}$.

\section{Data availability}

The model output data that support the findings of this study are available for download from Australia's National Computing Infrastructure (NCI) at https://researchdata.ands. org.au/marine-nitrogen-fixers-output-v10/1385710 with the identifier https://doi.org/ $10.25914 / 5 \mathrm{~d} 730 \mathrm{c} 40 \mathrm{c} 2729$. Source data underlying Figs. 2 and 3 are provided in the 
Supplementary information as a source data file. Glacial-interglacial differences in $\delta^{15} \mathrm{~N}_{\text {org }}$ are held in Supplementary Data 1. Code for making Figs. 1-4 is freely available at https://github.com/pearseb/Marine-nitrogen-fixers-paper-python-code.

\section{Code availability}

The source code for CSIRO Mk3L-COAL is shared via a repository located at http://svn. tpac.org.au/repos/CSIRO_Mk3L/branches/CSIRO_Mk3L-COAL/. Access to the repository may be obtained by following the instructions at https://www.tpac.org.au/ csiro-mk3l-access-request/. Access to the source code is subject to a bespoke license that does not permit commercial usage, but is otherwise unrestricted. An "out-of-the-box" run directory is also available for download with all files required to run the model in the configuration used in this study, although users will need to modify the runscript according to their computing infrastructure. Any queries may be directed to the lead author.

Received: 22 March 2019; Accepted: 16 September 2019;

Published online: 10 October 2019

\section{References}

1. Kohfeld, K. E. Role of marine biology in glacial-interglacial $\mathrm{CO}_{2}$ cycles. Science 308, 74-78 (2005).

2. Martinez-Garcia, A. et al. Iron fertilization of the subantarctic ocean during the last ice age. Science 343, 1347-1350 (2014).

3. Brunelle, B. G. et al. Glacial/interglacial changes in nutrient supply and stratification in the western subarctic North Pacific since the penultimate glacial maximum. Quat. Sci. Rev. 29, 2579-2590 (2010).

4. Martin, J. H. Glacial-interglacial $\mathrm{CO}_{2}$ change: the iron hypothesis. Paleoceanography 5, 1-13 (1990).

5. Lambert, F. et al. Dust fluxes and iron fertilization in Holocene and Last Glacial Maximum climates. Geophys. Res. Lett. 42, 6014-6023 (2015).

6. Tagliabue, a., Aumont, O. \& Bopp, L. The impact of different external sources of iron on the global carbon cycle. Geophy. Research Lett. 41, https://doi.org/ 10.1002/2013GL059059 (2014).

7. Muglia, J., Somes, C. J., Nickelsen, L. \& Schmittner, A. Combined effects of atmospheric and seafloor iron fluxes to the glacial ocean. Paleoceanography 32, 1204-1218 (2017).

8. Takahashi, T. et al. Global sea-air $\mathrm{CO}_{2}$ flux based on climatological surface ocean $\mathrm{pCO}_{2}$, and seasonal biological and temperature effects. Deep-Sea Res. Part II: Topical Stud. Oceanogr. 49, 1601-1622 (2002).

9. Emerson, S., Quay, P., Karl, D. M., Winn, C. \& Tupas, L. M. Experimental determination of the organic carbon flux from open-ocean surface waters. Nature 389, 951-954 (1997).

10. DeVries, T. \& Weber, T. The export and fate of organic matter in the ocean: new constraints from combining satellite and oceanographic tracer observations. Glob. Biogeochem. Cycles 31, 535-555 (2017).

11. Garcia, C. A. et al. Nutrient supply controls particulate elemental concentrations and ratios in the low latitude eastern Indian Ocean. Nat. Commun. 9, 4868 (2018).

12. Pavia, F. J. et al. Shallow particulate organic carbon regeneration in the South Pacific Ocean. Proc. Natl Acad. Sci. USA 116, 201901863 (2019).

13. Cavan, E. L., Trimmer, M., Shelley, F. \& Sanders, R. Remineralization of particulate organic carbon in an ocean oxygen minimum zone. Nat. Commun. 8, 14847 (2017).

14. Saito, M. A. et al. Multiple nutrient stresses at intersecting Pacific Ocean biomes detected by protein biomarkers. Science 345, 1173-1177 (2014).

15. Moore, C. M. et al. Processes and patterns of oceanic nutrient limitation. Nat. Geosci. 6, 701-710 (2013).

16. Browning, T. J. et al. Nutrient co-limitation at the boundary of an oceanic gyre. Nature 551, 242-246 (2017).

17. Falkowski, P. G. Evolution of the nitrogen cycle and its influence on the biological sequestration of $\mathrm{CO}_{2}$ in the ocean. Nature 387, 272-275 (1997).

18. Rubin, M., Berman-Frank, I. \& Shaked, Y. Dust-and mineral-iron utilization by the marine dinitrogen-fixer Trichodesmium. Nat. Geosci. 4, 529-534 (2011).

19. Polyviou, D. et al. Desert dust as a source of iron to the globally important diazotroph Trichodesmium. Front. Microbiol. 8, 1-12 (2018).

20. Karl, D. et al. The role of nitrogen fixation in biogeochemical cycling in the subtropical North Pacific Ocean. Nature 388, 533-538 (1997).

21. Karl, D. M., Church, M. J., Dore, J. E., Letelier, R. M. \& Mahaffey, C. Predictable and efficient carbon sequestration in the North Pacific Ocean supported by symbiotic nitrogen fixation. Proc. Natl Acad. Sci., USA 109, 1842-1849 (2012).

22. Shiozaki, T. et al. Linkage between dinitrogen fixation and primary production in the oligotrophic south pacific ocean. Glob. Biogeochem. Cycles 32, 1028-1044 (2018).
23. Ko, Y. H. et al. Carbon-based estimate of nitrogen fixation-derived net community production in N-depleted ocean gyres. Global Biogeoche. Cy. 32, 1241-1252 (2018).

24. Wang, W. L., Moore, J. K., Martiny, A. C. \& Primeau, F. W. Convergent estimates of marine nitrogen fixation. Nature 566, 205-211 (2019).

25. Dyhrman, S. T. et al. Phosphonate utilization by the globally important marine diazotroph Trichodesmium. Nature 439, 68-71 (2006).

26. Landolfi, A., Koeve, W., Dietze, H., Kähler, P. \& Oschlies, A. A new perspective on environmental controls of marine nitrogen fixation. Geophys. Res. Lett. 42, 4482-4489 (2015).

27. White, A. E., Spitz, Y. H., Karl, D. M. \& Letelier, R. M. Flexible elemental stoichiometry in Trichodesmium spp. and its ecological implications. Limnol. Oceanogr. 51, 1777-1790 (2006).

28. Nuester, J., Vogt, S., Newville, M., Kustka, A. B. \& Twining, B. S. The unique biogeochemical signature of the marine diazotroph Trichodesmium. Front. Microbiol. 3, 1-15 (2012).

29. Fu, F. X. et al. Differing responses of marine N2 fixers to warming and consequences for future diazotroph community structure. Aquat. Microb. Ecol. 72, 33-46 (2014).

30. Moore, K., Doney, S. C., Lindsay, K., Mahowald, N. \& Michaels Anthony, F. A. F. Nitrogen fixation amplifies the ocean biogeochemical response to decadal timescale variations in mineral dust deposition. Tellus, Ser. B: Chem. Phys. Meteorol. 58, 560-572 (2006).

31. Kienast, S. S., Winckler, G., Lippold, J., Albani, S. \& Mahowald, N. M. Tracing dust input to the global ocean using thorium isotopes in marine sediments: ThoroMap. Glob. Biogeochem. Cycles 30, 1526-1541 (2016).

32. Loveley, M. R. et al. Millennial-scale iron fertilization of the eastern equatorial Pacific over the past 100,000 years. Nat. Geosci. 10, 760-764 (2017).

33. Buchanan, P., Matear, R., Chase, Z., Phipps, S. \& Bindoff, N. Dynamic Biological Functioning Important for Simulating and Stabilizing Ocean Biogeochemistry. Global Biogeoche.Cy. 32, 565-593 (2018).

34. Buchanan, P. J., Matear, R. J., Chase, Z., Phipps, S. J. \& Bindoff, N. L. Ocean carbon and nitrogen isotopes in CSIRO Mk3L-COAL version 1.0: a tool for palaeoceanographic research. Geoscientific Model Dev. 12, 1491-1523 (2019).

35. Mahowald, N. M. et al. Atmospheric global dust cycle and iron inputs to the ocean. Global Biogeoche. Cy. 19, https://doi.org/10.1029/2004GB002402 (2005).

36. Garcia, H. E. et al. World Ocean Atlas 2013. Vol. 4: Dissolved Inorganic Nutrients (phosphate, nitrate, silicate). (ed. S. Levitus; Technical Ed. A. Mishonov). Tech. Rep (2013).

37. Sigman, D. M., Hain, M. P. \& Haug, G. H. The polar ocean and glacial cycles in atmospheric $\mathrm{CO}_{2}$ concentration. Nature 466, 47-55 (2010).

38. Buchanan, P. J. et al. The simulated climate of the Last Glacial Maximum and insights into the global marine carbon cycle. Climate 12, 2271-2295 (2016).

39. Karl, D. M. \& Letelier, R. M. Nitrogen fixation-enhanced carbon sequestration in low nitrate, low chlorophyll seascapes. Mar. Ecol. Prog. Ser. 364, 257-268 (2008).

40. Ren, H. et al. Impact of glacial/interglacial sea level change on the ocean nitrogen cycle. Proc. Natl Acad. Sci. USA 114, E6759-E6766 (2017).

41. Ganeshram, R. S. et al. Large changes in oceanic nutrient inventories from glacial to interglacial periods. Nature 376, 755-758(1995).

42. Straub, M. et al. Changes in North Atlantic nitrogen fixation controlled by ocean circulation. Nature 501, 200-203 (2013).

43. Francois, R. et al. Contribution of Southern Ocean surface-water stratification to low atmospheric $\mathrm{CO}_{2}$ concentrations during the last glacial period. Nature 389, 929-935 (1997).

44. Studer, A. S. et al. Antarctic Zone nutrient conditions during the last two glacial cycles. Paleoceanography 30, 845-862 (2015).

45. Muglia, J., Skinner, L. C. \& Schmittner, A. Weak overturning circulation and high Southern Ocean nutrient utilization maximized glacial ocean carbon. Earth. Planet. Sci. Lett. 496, 47-56 (2018).

46. Schmittner, A. \& Somes, C. J. Complementary constraints from carbon (13C) and nitrogen $(15 \mathrm{~N})$ isotopes on the glacial ocean's soft-tissue biological pump. Paleoceanography 31, 669-693 (2016).

47. Sarmiento, J. L., Gruber, N., Brzezinski, Ma \& Dunne, J. P. High-latitude controls of thermocline nutrients and low latitude biological productivity. Nature 427, 56-60 (2004).

48. Jacobel, A. W. et al. No evidence for equatorial Pacific dust fertilization. Nat. Geosci. 12, 154-155 (2019).

49. Marcantonio, F., Loveley, M. R., Schmidt, M. W. \& Hertzberg, J. E. Reply to: No evidence for equatorial Pacific dust fertilization. Nat. Geosci. 12, 156-156 (2019).

50. Christensen, J. P., Murray, J. W., Devol, A. H. \& Codispoti, La Denitrification in continental shelf sediments has major impact on the oceanic nitrogen budget. Glob. Biogeochem. Cycles 1, 97 (1987).

51. Hoogakker, B. A. et al. Glacial expansion of oxygen-depleted seawater in the eastern tropical Pacific. Nature 562, 410-413 (2018).

52. Anderson, R. F. et al. Deep-sea oxygen depletion and ocean carbon sequestration during the last ice age. Glob. Biogeochem. Cycles 33, 301-317 (2019). 
53. Cartapanis, O., Bianchi, D., Jaccard, S. L. \& Galbraith, E. D. Global pulses of organic carbon burial in deep-sea sediments during glacial maxima. Nat. Commun. 7, 1-7 (2016).

54. DeVries, T., Deutsch, C., Rafter, P. A. \& Primeau, F. Marine denitrification rates determined from a global 3-D inverse model. Biogeosciences 10 2481-2496 (2013).

55. Costa, K. M. et al. Productivity patterns in the equatorial Pacific over the last 30,000 years. Glob. Biogeochem. Cycles 31, 850-865 (2017).

56. Galbraith, E. D. \& Martiny, A. C. A simple nutrient-dependence mechanism for predicting the stoichiometry of marine ecosystems. Proc. Natl Acad. Sci. USA 112, 201423917 (2015).

57. Sherwood, O. A., Guilderson, T. P., Batista, F. C., Schiff, J. T. \& McCarthy, M. D. Increasing subtropical north Pacific Ocean nitrogen fixation since the Little Ice Age. Nature 505, 78-81 (2014)

58. McMahon, K. W., McCarthy, M. D., Sherwood, O. A., Larsen, T. \& Guilderson, T. P. Millennial-scale plankton regime shifts in the subtropical North Pacific. Ocean. Sci. 350, 1530-1533 (2015).

59. Stramma, L., Johnson, G. C., Sprintall, J. \& Mohrholz, V. Expanding oxygenminimum zones in the tropical oceans. Science 320, 655-658 (2008).

60. Schmidtko, S., Stramma, L. \& Visbeck, M. Decline in global oceanic oxygen content during the past five decades. Nature 542, 335-339 (2017).

61. Hutchins, D. A. \& Boyd, P. W. Marine phytoplankton and the changing ocean iron cycle. Nat. Clim. Change 6, 1072-1079 (2016).

62. Phipps, S. J. et al. Paleoclimate data-model comparison and the role of climate

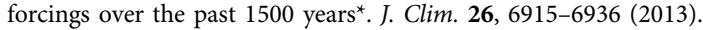

63. Orr, J. C. et al. Biogeochemical protocols and diagnostics for the CMIP6 Ocean Model Intercomparison Project (OMIP). Geoscientific Model Dev. 10, 2169-2199 (2017).

64. Lamarque, J. F. et al. Multi-model mean nitrogen and sulfur deposition from the atmospheric chemistry and climate model intercomparison project (ACCMIP): Evaluation of historical and projected future changes. Atmos Chem. Phys. 13, 7997-8018 (2013).

65. Kustka, A., Sañudo-Wilhelmy, S., Carpenter, E. J., Capone, D. G. \& Raven, Ja A revised estimate of the iron use efficiency of nitrogen fixation, with special reference to the marine cyanobacterium Trichodesmium spp. (Cyanophyta). J. Phycol. 39, 12-25 (2003).

66. Mills, M. M. \& Arrigo, K. R. Magnitude of oceanic nitrogen fixation influenced by the nutrient uptake ratio of phytoplankton. Nat. Geosci. 3, 412-416 (2010).

67. Paulmier, a, Kriest, I. \& Oschlies, A. Stoichiometries of remineralisation and denitrification in global biogeochemical ocean models. Biogeosciences $\mathbf{6}$ 923-935 (2009).

68. Kriest, I. \& Oschlies, A. MOPS-1.0: towards a model for the regulation of the global oceanic nitrogen budget by marine biogeochemical processes. Geosci. Model Dev. 8, 2929-2927 (2015).

69. Sipler, R. E. et al. Preliminary estimates of the contribution of Arctic nitrogen fixation to the global nitrogen budget. Limnol Oceanogr. Lett. 2, 159-166 (2017).

70. Luo, Y. W., Lima, I. D., Karl, D. M., Deutsch, C. A. \& Doney, S. C. Data-based assessment of environmental controls on global marine nitrogen fixation. Biogeosciences 11, 691-708 (2014).

71. McGillicuddy, D. J. Do Trichodesmium spp. populations in the North Atlantic export most of the nitrogen they fix? Glob. Biogeochem. Cycles 28, 103-114 (2014).

72. Bohlen, L., Dale, A. W. \& Wallmann, K. Simple transfer functions for calculating benthic fixed nitrogen losses and $\mathrm{C}: \mathrm{N}: \mathrm{P}$ regeneration ratios in global biogeochemical models. Global Biogeochem.Cy. 26, https://doi.org/ 10.1029/2011GB004198 (2012).

73. Gundersen, J. K. \& Jorgensen, B. B. Microstructure of diffusive boundary layers and the oxygen uptake of the sea floor. Nature 345, 604-607 (1990)

74. Somes, C. J., Oschlies, A. \& Schmittner, A. Isotopic constraints on the preindustrial oceanic nitrogen budget. Biogeosciences 10, 5889-5910 (2013).

75. Taylor, K. E., Stouffer, R. J. \& Meehl, G. A. An overview of CMIP5 and experimental design. Bull. Am. Meteorological Soc. 93, 485-498 (2012).

\section{Acknowledgements}

We wish to thank the Australian Research Council's Centre of Excellence for Climate System Science, CSIRO Oceans and Atmosphere and the Tasmanian Partnership for Advanced Computing (TPAC) for facilitating the research. This research was partly supported by the CSIRO Decadal Climate Forecasting Project, the Australian Research Council's Special Research Initiative for the Antarctic Gateway Partnership (Project ID SR140300001), and through funding from the Australian Governments National Environmental Science Program Earth Systems and Climate Change Hub, which was supported by the National Environmental Science Program. We acknowledge the World Climate Research Programme's Working Group on Coupled Modelling, which is responsible for CMIP, and we thank the climate modeling groups (GFDL-ESM2G and HadGEM2-CC, listed in Table 1 of Buchanan et al. ${ }^{33}$ ) for producing and making available their model output. For CMIP the U.S. Department of Energy's Program for Climate Model Diagnosis and Intercomparison provides coordinating support and led development of software infrastructure in partnership with the Global Organization for Earth System Science Portals. We thank Toño Gomez for his preparation of Fig. 5 and acknowledge the Australian-American Fulbright Commission for a postgraduate scholarship that allowed the lead author to complete this work.

\section{Author contributions}

P.J.B. developed the biogeochemical model code, designed and executed the experiments, collated the $\delta^{15} \mathrm{~N}$ data, analysed and interpreted the results, and prepared and edited the paper. Z.C. designed the experiments, interpreted the results and wrote the paper. R.J.M performed key early development of biogeochemical model code, interpreted the result and edited the paper. S.J.P. performed key early development of the climate system model and edited the paper. N.L.B. interpreted the results and edited the paper.

\section{Competing interests}

The authors declare no competing interests.

\section{Additional information}

Supplementary information is available for this paper at https://doi.org/10.1038/s41467 019-12549-z.

Correspondence and requests for materials should be addressed to P.J.B.

Peer review information Nature Communications thanks Jennifer Hertzberg and the other, anonymous, reviewer(s) for their contribution to the peer review of this work. Peer reviewer reports are available.

Reprints and permission information is available at http://www.nature.com/reprints

Publisher's note Springer Nature remains neutral with regard to jurisdictional claims in published maps and institutional affiliations.

Open Access This article is licensed under a Creative Commons Attribution 4.0 International License, which permits use, sharing, adaptation, distribution and reproduction in any medium or format, as long as you give appropriate credit to the original author(s) and the source, provide a link to the Creative Commons license, and indicate if changes were made. The images or other third party material in this article are included in the article's Creative Commons license, unless indicated otherwise in a credit line to the material. If material is not included in the article's Creative Commons license and your intended use is not permitted by statutory regulation or exceeds the permitted use, you will need to obtain permission directly from the copyright holder. To view a copy of this license, visit http://creativecommons.org/ licenses/by/4.0/

(C) The Author(s) 2019 